\title{
ANALISIS PEMAHAMAN KONSEP SAINS GURU KELAS MADRASAH IBTIDAIYAH
}

\author{
Agus Mukti Wibowo ${ }^{1}$
}

\section{Abstract}

Most of the concepts in science are abstract ones. These concepts tend to be difficult to study by students who have not developed formal thinking ability. This difficulty may cause misconception, i.e. students' conceptions which are different from those generally accepted by the scientific community. Understanding of teacher in non PGMI / PGSD on material science at Islamic Elementary School is still considered to be lacking or need improvement. Misconception that occurs teacher non PGMI / PGSD to learning materials science at Islamic Elementary School almost occurred in all of the material, among other things, the material of plant, animal material changes (water and solvent) light and the solar system

Keywords: Keywords: material science, scientific, misconception

\section{A. Pendahuluan}

Lingkup Ilmu Pengetahuan Alam atau Sains mencakup materi yang sangat luas meliputi fakta, konsep, aturan, hukum prinsip, teori dan soal-soal (Middlecamp \& Kean, 1985:8). Dari cakupan materi Ilmu Pengetahuan Alam tersebut sebagian besar dari konsep-konsepnya bersifat abstrak dan sangat kompleks seperti konsep tentang perubahan fisika maupun perubahan Ilmu Pengetahuan Alam.

Menurut Middlecamp dan Kean (1985) karakteristik dari Ilmu Pengetahuan Alam antara lain adalah bersifat abstrak, konsepkonsepnya disederhanakan dari yang sebenarnya dan konsepkonsepnya saling berkaitan dan berurutan. Akibat dari sifat dari Ilmu Pengetahuan Alam tersebut, maka diperlukan waktu yang lebih lama untuk memahaminya dengan benar. Pemahaman merupakan salah satu faktor penting dalam belajar. Menurut Nakhleh (1992:191) kesulitan-kesulitan dalam memahami konsep-konsep dasar dengan tepat akan menghambat peserta didik dan mahapeserta didik dalam mengkaitkan konsep-konsep dasar tersebut dengan konsep-konsep

1 Dosen Fakultas Ilmu Tarbiyah dan Keguruan UIN Maulana Malik Ibrahim Malang 
lain yang berhubungan. Kondisi ini memungkinkan timbulnya pemahaman yang salah terhadap suatu konsep. Jika kesalahan ini terjadi secara terus menerus (konsisten) maka dapat dikatakan mengalami kesalahan konsep (misconception) (Berg, 1988:26). Konsistensi kesalahan dapat diidentifikasi dengan mengujikan beberapa soal dengan dasar konseptual yang sama atau dengan melihat konsistensi jawaban tes tertulis dengan wawancara.

Penelitian yang dilakukan oleh Nakhleh (1992) menunjukkan bahwa kesalahan konsep telah terjadi pada hampir semua pokok bahasan. Kesalahan konsep itu terutama terjadi pada konsepkonsep yang abstrak seperti fotosintesis, gerak gaya maupun energi. Kesalahan konsep yang terjadi pada peserta didik dapat berasal dari berbagai sumber. Menurut Herron (1996) kesalahan konsep peserta didik dapat berasal dari kesalahan pemahaman peserta didik sendiri, kesalahan pemahaman bahan ajar yang disampaikan oleh guru, atau kesalahan pemahaman dari guru itu sendiri. Altun dan Kaya (1996) menyatakan bahwa hubungan antara konsep seorang guru dengan konsep yang diperoleh oleh peserta didiknya adalah sangat kuat. Untuk itu diperlukan sebuah pemahaman yang baik dari seorang guru atau pendidik sehingga pemahaman yang diperoleh siswa tidak mengalami kesalahan konsep atau dalam arti pemahaman konsepnya semakin baik

Bodner (1992) menyatakan bahwa dalam kegiatan pembelajaran, perbaikan kesalahan konsep tidak mudah dilakukan, karena konsep yang salah tersebut sukar untuk ditinggalkan. Pernyataan ini identik dengan pendapat Carey (dalam Suparno, 1997) bahwa usaha untuk mengubah kesalahan pemahaman bukanlah sesuatu yang mudah. Perubahan pemahaman suatu konsep yang salah baru berhasil jika terjadi proses rekonstruksi yang kuat. Salah satu cara perubahan konsep menurut Posner, Strike, Hewson \& Gerzog (1982) yaitu dengan menimbulkan suatu peristiwa atau anomali yang bertentangan dengan apa yang dipikirkan peserta didik, sehingga akan terjadi ketidakpuasan peserta didik terhadap konsep lama dan pada akhirnya akan mengubah konsep tersebut. Pemberian peristiwa atau anomali yang bertentangan dengan yang dipikirkan peserta didik tidak harus menggunakan suatu strategi atau metode pembelajaran saja, tetapi dapat juga digunakan suatu materi yang mencakup peristiwa atau anomali tersebut serta pengetahuan guru terhadap konsep tersebut. 
Materi Ilmu Pengetahuan Alam meliputi banyak konsep, beberapa diantaranya adalah konsep tentang makhluk hidup yang meliputi tumbuhan, hewan dan manusia serta benda tidak hidup yang meliputi alam semesta, benda dan perubahannya, gaya gerak maupun energi. Materi Ilmu Pengetahuan Alam yang sangat bervariasi tersebut akan menuntut pemahaman konsep dari guru atau pendidik yang mumpuni. Agar peserta didik dapat mempelajari konsepkonsep tersebut dengan baik, maka diperlukan pemahaman konsep yang benar dari guru atau pendidik. Sebaik apapun cara mengajar seorang guru, jika konsep yang disampaikan mengalami kesalahan konsep atau miskonsepsi maka siswa atau peserta didik dimungkinkan akan mengalami kesalahan konsep.

Untuk itu diperlukan adanya analisis terhadap pemahaman guru kelas Madrasah Ibtidaiyah Non PGMI/PGSD terhadap materi sains di Madrasah Ibtidaiyah..

\section{B. Karakteristik Konsep Sains}

Dalam ilmu pengetahuan alam atau sains, konsep memiliki karakteristik tertentu. Sastrawijaya (1988:87) menyatakan konsep dalam sains merupakan konsep yang berjenjang dari yang sederhana ke konsep yang lebih tinggi tingkatannya. Sehingga dalam memahami konsep yang lebih tinggi diperlukan pemahaman yang benar terhadap konsep yang membangun konsep tersebut. Misalnya untuk memahami konsep benda miring, katrol, jungkat jungkit atau lebih dikenal pesawat sederhana dengan benar diperlukan pemahaman yang benar tentang konsep-konsep lain yang mendasarinya, antara lain konsep tentang gerak dan gaya.

Menurut Middlecamp dan Kean (1984:4) konsep (bagian dari sains) memiliki karakteristik; (1) sebagian besar bersifat abstrak, (2) k pada umumnya merupakan penyederhanaan dari keadaan yang sebenarnya, (3) berurutan. Sedangkan menurut Effendy (2002) konsep (merupakan bagian dari sains) memiliki karakteristik, yaitu makna ganda atau memiliki arti lebih dari satu, misalnya bilangan oksidasi dapat didefinisikan (1) sebagai banyaknya pasangan elektron dan pasangan elektron bebas yang terdapat pada kulit valensi atom pusat suatu molekul atau ion. (2) Banyaknya atom yang terikat pada atom sejenis dengan jarak terdekat yang sama dengan kristal logam. (3) Banyaknya atom donor yang terikat pada atom pusat dalam suatu 
kompleks. (4) Banyaknya ion-ion yang sejenis yang terikat oleh sebuah ion dengan muatan berlawanan dengan jarak yang terdekat yang sama pada kristal ion. Di samping itu, konsep ada yang memiliki arti yang berlawanan, misalnya oksidasi reduksi. Konsep sains juga bisa merupakan gabungan dari konsep-konsep yang sederhana, misalnya konsep tentang percepatan yang merupakan gabungan konsep panjang lintasan, konsep tentang pengukuran panjang dan waktu serta konsep tentang perubahan kecepatan. Karakteristik dari konsep yang demikian memungkinkan pemahaman siswa menjadi tidak tepat dan dapat menimbulkan kesalahan yang konsisten.

\section{Pentingnya Pemahaman Konsep Secara Tepat}

Dalam mempelajari konsep Sains, siswa banyak dikenalkan dengan konsep-konsep yang abstrak (Wiseman, 1981), maka untuk pengungkapan konsep yang abstrak tersebut guru atau dalam buku teks memberikan gambaran atau definisi yang mewakili konsep tersebut. Menurut Ibnu (1989) kadangkala siswa mengidentikkan antara konsep sebenarnya dengan obyek yang dijadikan sebagai gambaran konsep tersebut. Hal ini akan menyulitkan siswa dalam memahami konsep atau bahkan berimplikasi pada salah satu konsep. Di samping abstrak, konsep dalam ilmu dapat memiliki arti lebih dari satu arti dan setiap konsep tidak dapat berdiri sendiri seperti pada contoh karakteristik konsep. Fenomena ini menunjukkan pentingnya pemahaman konsep yang benar dalam mempelajari konsep-konsep dalam ilmu .

Pemahaman konsep yang benar merupakan landasan yang memungkinkan terbentuknya pemahaman yang benar terhadap konsep-konsep lain yang berhubungan atau konsep yang lebih kompleks, fakta, hukum, prinsip dan teori-teori dalam ilmu. Terlebih lagi jika diingat bahwa salah satu karakteristik dari konsep ilmu adalah adanya saling keterkaitan dan berkembang dari konsep yang sederhana menuju konsep yang lebih kompleks (Middlecamp dan Kean, 1989:8; Sastrawijaya, 1988:103). Pemahaman suatu konsep yang tidak benar memungkinkan terbentuknya konsep-konsep lain yang berkaitan tidak benar pula.

Menurut Dahar (1989:79), untuk dapat memecahkan masalah seseorang harus mengetahui aturan-aturan yang relevan dan aturanaturan ini didasarkan pada konsep yang diperolehnya. Dengan 
demikian dapat dikatakan bahwa konsep merupakan batu pembangun berfikir, sehingga pemahaman konsep yang benar menjadi sangat penting untuk dimiliki. Pemahaman konsep yang benar merupakan landasan dalam memahami fakta-fakta, hukum-hukum, prinsipprinsip dan teori-teori dalam ilmu secara benar. Selain itu, pemahaman konsep secara benar akan menghasilkan penerapan konsep yang benar sebagai landasan untuk memecahkan masalah dalam kehidupan sehari-hari dan iptek yang sangat cepat perkembangannya.

\section{Teori Tentang Pemerolehan Konsep}

Pengetahuan adalah bentukan (konstruksi) pribadi yang sedang menekuninya (Graserfield dalam Suparno, 1997). Pengetahuan merupakan bentukan dari seseorang yang sedang menekuninya, bukan sesuatu yang sudah jadi tetapi harus dibentuk dalam pikiran. Proses pembentukan akan terus berjalan setiap kali terjadi reorganisasi karena adanya pemahaman baru.

Konsep-konsep yang diperoleh oleh siswa untuk dibangun dalam otaknya merupakan suatu pengetahuan yang dibangun dengan mengikuti pola-pola aturan tertentu. Hal tersebut berkaitan dengan pola-pola pemerolehan konsep yang telah banyak dikemukakan oleh para ahli diantaranya oleh Bruner, Auseble, Osborne, Wittrock dan Piaget.

Pemerolehan konsep menurut Bruner, menekankan belajar dengan cara penemuan. Pendekatan Bruner tentang belajar penemuan didasarkan pada dua asumsi. Asumsi yang pertama, pemerolehan pengetahuan merupakan suatu proses interakstif dimana individu yang belajar berinteraksi dengan lingkungannya, tetapi juga pada diri individu itu. Asumsi yang kedua, individu membangun pengetahuannya dengan menghubungkan informasi baru dengan pengetahuan yang telah diperoleh sebelumnya (Dahar, 1989:119).

Pendekatan Bruner terhadap belajar dapat diuraikan sebagai suatu pendekatan kategorisasi. Bruner beranggapan, bahwa semua interaksi-interaksi kita dengan alam melibatkan kategori-kategori yang dibutuhkan bagi pemungsian manusia. Ringkasnya, bahwa belajar merupakan pengembangan kategori-kategori dan pengembangan suatu sistem pengkodean (coding). 
Pemerolehan konsep menurut Ausubel, menekankan pada belajar bermakna yang merupakan suatu proses belajar dimana informasi dikaitkan pada konsep-konsep relevan yang telah ada dalam struktur kognitif. Konsep yang telah ada dapat berfungsi sebagai pengatur awal untuk menghubungkan dan membantu memahami konsep baru yang diterimanya. Struktur kognitif yang dimiliki siswa dapat berupa bangunan konsep yang saling berkaitan satu sama lain dan dapat pula berupa sekumpulan konsep yang berdiri sendiri. Jenis struktur kognitif ini berhubungan dengan ciri ilmu yang dipelajari serta sumber proses belajar yang diterapkan dalam mempelajari suatu ilmu. Proses pembentukan struktur kognitif yang diharapkan adalah menghasilkan prinsip belajar bermakna.

Struktur kognitif adalah fakta-fakta, konsep-konsep dan generalisaasi-generalisasi yang telah dipelajari dan diingat oleh siswa. Menurut Ausubel (dalam Dahar, 1989:134), konsep-konsep diperoleh dengan dua cara, yaitu formasi konsep (concept formation) dan asimilasi konsep (concept asimilation). Pembentukan konsep merupakan merupakan bentuk perolehan konsep-konsep sebelum dan setelah anak-anak masuk sekolah yang melibatkan prosesproses psikologis seperti analisis diskriminasi, abstraksi, diferensiasi, pembentukan hipotesis dan pengujian, dan generalisasi. Asimilasi konsep merupakan cara untuk memperoleh konsep-konsep selama dan sesudah sekolah yang diawali dengan penyajian tentang definisi formal dari konsep-konsep itu.

\section{Kesalahan Konsep dalam Sains}

Konsep merupakan batu pembangun (building blocks) berpikir dan juga sebagai dasar bagi proses-proses mental yang lebih tinggi untuk merumuskan prinsip-prinsip dan generalisasi-generalisasi (Dahar, 1988). Setiap konsep tidak berdiri sendiri, tetapi saling berhubungan antara konsep yang satu dengan konsep yang konsep yang lain. Konsep-konsep tersebut membentuk semacam jaringan pengetahuan di dalam kepala manusia. Seringkali dalam belajar siswa hanya menghafalkan konsep definisi tanpa memperhatikan hubungan antar konsep. Dengan demikian konsep baru tidak masuk dalam jaringan konsep yang telah ada melainkan akan berdiri sendiri tanpa ada hubungan dengan konsep yang lain (Berg, 1991). Kondisi ini dapat memungkinkan siswa mengalami salah konsep 
atau miskonsepsi. Sebagai contoh adalah siswa menyatakan bahwa terjadinya fotosintesis pada tumbuhan karena adanya zat klorofil dan sinar matahari. Klorofil adalah zat hijau daun dan dimaknai sebagai daun yang berwarna hijau dan berfungsi menangkap cahaya matahari. Kemudian mereka mendapat konsep baru bahwa setiap makhluk hidup yang memiliki klorofil dapat melakukan fotosintesis, contohnya tumbahan atau bakteri yang memiliki klorofil b. Jika siswa tidak mengetahui konsep tentang klorofil dan makhluk hidup yang mampu melakukan fotosintesis, maka siswa akan cenderung menyatakan bahwa klorofil adalah zat yang ada pada daun tumbuhan yang berwarna hijau. Lebih lanjut, jika kesalahan ini tidak diperbaiki maka siswa akan menganggap bahwa mahkhluk yang dapat melakukan fotosintesis adalah tumbuhan saja.

Uraian di atas menunjukkan bahwa kesalahan konsep dapat didefinisikan sebagai pemahaman oleh siswa atas konsep-konsep yang berbeda dengan apa yang dimaksud oleh buku acuan atau para ahli (masyarakat ilmiah) yang secara konsisten menyebabkan siswa ataupun mahasiswa melakukan kesalahan dalam memahami konsep (Taber, 1994). Kesalahan konsep yang terjadi dapat terjadi akibat interaksi antara siswa dan guru atau dengan buku-buku pelajaran (Griffiths dan Preston, 1992). Kesalahan konsep tersebut jika tidak diperbaiki akan menggangu pemikiran siswa dalam menerima pengetahuan berikutnya. Oleh karena itu perlu dilakukan perbaikan untuk meningkatkan hasil belajar siswa.

\section{Rancangan Penelitian}

Sesuai dengan tujuan penelitian, yaitu untuk mengetahui tingkat pemahaman dan kesalahan konsep Sains yang terjadi pada guru kelas MI non PGMI/PGSD maka penelitian ini menggunakan rancangan penelitian deskriptif.

Rancangan deskriptif digunakan untuk mendiskripsikan pemahaman guru kelas MI non PGMI/PGSD. Wawancara secara terstruktur terhadap guru kelas MI non PGMI/PGSD dilakukan untuk mengetahui sumber-sumber kesalahan dalam pemahaman.

Tahap-tahap dalam penelitian adalah sebagai berikut:

1. Pengkajian konsep-konsep Sains di MI

2. Penyusunan Instrumen dan validasi instrumen 
3. Melakukan tes untuk mengetahui pemahaman maupun kesalahan konsep guru kelas MI non PGMI/PGSD

4. Wawancara terhadap sampel penelitian

5. Analisis kesalahan konsep yang terjadi pada guru kelas MI non PGMI/PGSD

6. Analisis data

\section{Analisis Data}

Analisa data yang dilakukan adalah analisis materi Sains yang diajarkan di Madrasah Ibtidaiyah tempat sampel penelitian. Data penelitian yang diperoleh dianalisis secara diskriptif.

Langkah-langkah dalam analisis pemahaman maupun kesalahan terhadap materi Sains di Madrasah Ibtidaiyah tempat sampel penelitian adalah:

1. Menganalisis tentang isi dari materi sains yang diajarkan di Madrasah Ibtidaiyah

2. Menganalisis tentang kecukupan isi dari materi sains yang diajarkan di Madrasah Ibtidaiyah

Untuk menentukan konsistensi tingkat pemahaman maupun kesalahan guru kelas Non PGMI/PGSD dilakukan dengan dua cara yaitu:

1. Konsistensi jawaban pada tes tulis

2. Konsistensi jawaban pada tes tulis dengan jawaban pada wawancara

\section{E. Hasil dan Pembahasan}

Berdasarkan hasil jawaban tes tulis maka kesalahan konsep yang terjadi dalam pembelajaran Ilmu Pengetahuan Alam atau Sains di Madrasah Ibtidaiyah adalah sebagai berikut:

\section{Pemetaan Pemahaman dan Kesalahan Konsep dalam Sains}

Pemahaman tentang konsep-konsep Sains dalam pembelajaran di tingkat Madrasah Ibtidaiyah bagi guru kelas Non PGMI masih cukup rendah. Hal ini dapat dilihat dari konsep-konsep yang dikuasai oleh mereka. Konsep yang dikuasai terkesan tidak utuh, baik konsep 
tentang tumbuhan yang meliputi fotosintesis, sistem pernafasan ataupun sistem perkembangbiakan. Demikian halnya dengan konsep tentang hewan maupun tentang perubahan benda.

Berdasarkan hasil jawaban dan wawancara terhadap responden diperoleh data sebagai berikut:

\begin{tabular}{|c|c|c|}
\hline No & Materi/bahasan & Konsep \\
\hline 1 & Tumbuhan & $\begin{array}{ll}\text { i. } & \begin{array}{l}\text { Klorofil adalah zat hijau daun yang terdapat } \\
\text { pada tumbuhan dengan daun yang berwarna }\end{array} \\
\text { hijau. } \\
\text { ii. } & \begin{array}{l}\text { Klorofil digunakan untuk menangkap cahaya } \\
\text { matahari }\end{array} \\
\text { iii. } & \begin{array}{l}\text { Fotosintesis hanya dapat terjadi pada } \\
\text { tumbuhan }\end{array} \\
\text { iv. } & \begin{array}{l}\text { Fotosintesis hanya dapat berlangsung dengan } \\
\text { menggunakan cahaya matahari. }\end{array} \\
\text { v. } & \begin{array}{l}\text { Tumbuhan bernapas pada siang hari, } \\
\text { sebagian mengatakan bahwa tumbuhan }\end{array} \\
\text { vernafas menghirup } \mathrm{CO}_{2} \\
\text { vi. } & \begin{array}{l}\text { Kacang tanah termasuk tumbuhan berakar } \\
\text { serabut, dan tumbuh dengan tunas terlebih } \\
\text { dahulu. }\end{array} \\
\end{array}$ \\
\hline 2 & Hewan & \begin{tabular}{|ll} 
i. & Semua hewan di air (ikan) bernafas \\
menggunakan insang & Bunyi pada ikan lumba-lumba \\
ii. & Bumber \\
\end{tabular} \\
\hline 3 & Air & $\begin{array}{ll}\text { i. } & \text { Air laut berwarna biru karena merefleksikan } \\
\text { ii. } & \text { Air selalu bergerak dari atas ke bawah }\end{array}$ \\
\hline 4 & Panas dan Suhu & $\begin{array}{l}\text { Panas identik dengan suhu, jika suhunya tinggi } \\
\text { maka panasnya akan semakin tinggi demikian } \\
\text { sebaliknya, tetapi jika suhunya sama maka dapat } \\
\text { dipastikan panasnya juga sama. }\end{array}$ \\
\hline 5 & Cahaya & $\begin{array}{l}\text { Cahaya pelangi hanya dapat terjadi pada musim } \\
\text { hujan, karena pelangi hanya dapat dihasilkan oleh } \\
\text { hujan }\end{array}$ \\
\hline 6 & Tata Surya & $\begin{array}{l}\text { Matahari selalu terbit dari timur dan tenggelam di } \\
\text { sebelah barat }\end{array}$ \\
\hline
\end{tabular}

Data di atas menunjukkan bahwa kesalahan konsep yang terjadi cukup variatif, meskipun belum mencakup keseluruhan dari materi sains di Madrasah Ibtidaiyah, dikarenakan keterbatasan jawaban yang mampu diberikan oleh responden.

\section{Analisis Pemahaman Kesalahan Konsep}

Berdasarkan data tabel di atas maka, kesalahan konsep yang terjadi dapat dikelompokkan berdasarkan materi atau kajian sains. 
Materi atau bahan kajian sains berdasarkan kesalahan konsep di atas adalah sebagai berikut.

a. Tumbuhan

Berdasarkan data tabel di atas menunjukkan bahwa kesalahan konsep yang terjadi cukup banyak, meskipun pada dasarnya tidak dapat mencakup semua konsep yang ada pada materi sains tentang tumbuhan. Hal ini disebabkan karena keterbatasan jawaban yang diberikan responden baik yang tertulis maupun hasil wawancara.

Hasil tes tulis maupun wawancara menunjukkan bahwa kesalahan konsepyangterjadilebihdominan padakajian tentang fotosintesis. Sebagian besar responden mengatakan bahwa "fotosintesis hanya dapat terjadi pada tumbuhan, yang merupakan produsen makanan". Konsep seperti ini akan menyebabkan siswa memiliki pemahaman bahwa tidak ada makhluk hidup selain tumbuhan yang dapat berfotosintesis. Konsep ini akan bertentang dengan adanya fakta bahwa ada makhluk hidup selain tumbuhan yaitu sejenis bakteri yang mampu memproduksi makanannya sendiri karena memiliki klorofil b. Fakta ini menunjukkan bahwa semua mahkluk yang memiliki klorofil mampu melaksanakan fotosintesis jika syarat terjadinya terpenuhi.

Konsep tentang fotosintesis yang hanya dapat terjadi pada tumbuhan memiliki efek berantai terhadap konsep lain yang berhubungan, misalnya adanya klorofil adalah zat hijau daun yang dimaknai terdapat pada daun tumbuhan berwarna hijau yang memiliki fungsi menangkap cahaya, dan cahaya yang digunakan adalah cahaya matahari. Konsep-konsep seperti ini jika disampaikan dalam pembelajaran akan mengakibatkan siswa memiliki pemahaman yang salah atau salah konsep. Misalnya dalam konsep tentang klorofil adalah zat hijau daun dan dimaknai daun berwarna hijau, tentunya akan menimbulkan pertanyaan (1) bagaimana jika daunnya tidak berwarna hijau, (2) bagaimana dengan bakteri yang tidak memiliki daun tetapi memiliki klorofil b. Jika kita memiliki pemahaman yang cukup baik tentu hal tersebut dapat dihindari dan siswa atau peserta didik akan memiliki pemahaman yang benar. Klorofil dalam fotosintesis memiliki fungsi yang sangat signifikan, yaitu merubah energi 
cahaya menjadi energi kimia, jika tidak terbentuk energi kimia maka reaksi antara $\mathrm{H}_{2} \mathrm{O}$ dan $\mathrm{CO}_{2}$ tidak akan dapat membentuk $\mathrm{C}_{6} \mathrm{H}_{12} \mathrm{O}_{6}$, tetapi akan membentuk $\mathrm{H}_{2} \mathrm{CO}_{3}$. Energi cahaya yang dirubah oleh klorofil memiliki panjang gelombang tertentu, yaitu cahaya merah dan cahaya biru. Hal ini menunjukkan bahwa proses fotosintesis pada saat ini dapat direkayasa jika cahaya matahari yang diterima tumbuhan tidak mencukupi.

Kesalahan konsep yang juga terjadi pada materi tentang tumbuhan adalah adanya penyataan bahwa tumbuhan bernafas pada siang hari dan menghirup $\mathrm{CO}_{2}$. Pernyataan ini menunjukkan pemahaman yang salah terhadap konsep dari proses respirasi. Respirasi pada mahkluk hidup, termasuk juga tumbuhan adalah proses pengambilan $\mathrm{O}_{2}$ bukan $\mathrm{CO}_{2}$. Gas $\mathrm{CO}_{2}$ pada siang hari oleh tumbuhan digunakan untuk proses fotosintesis sedangkan pada proses respirasi baik siang maupun malam (sepanjang hari) tumbuhan memerlukan $\mathrm{O}_{2}$.

Konsep tentang materi tumbuhan yang juga dipahami secara kurang tepat adalah tentang contoh atau jenis akar tanaman, berdasarkan hasil wawancara menunjukkan bahwa ada sebagaian responden yang menyatakan bahwa kacang tanah adalah berakar serabut. Karakteristik kacang tanah adalah tumbuhan yang tumbuh dari biji berkeping dua, atau dikotil. Pertumbuhan kecambah kacang tanah akan dimulai dengan tumbuhnya akar terlebih dulu setelah itu tumbuh daun sepasang yang kemungkinan berasal dari dua keping dalam biji kacang. Pertumbuhan akar pada kecambah dari kacang tanah terlihat bahwa pertumbuhan akarnya adalah tunggang bukan serabut. Tumbuhan kacang tanahakanmenyimpancadangan makanannya pada akar, sehingga serabut dari akar tunggang (bukan akar serabut) akar terlihat seperti akar serabut. Hal ini berbeda pada pertumbuhan pada kelapa yang pertumbuhan daunnya tidak sepasang, tetapi satu daun secara bergantian yang dimungkinkan berasal dari satu keping biji kelapa. Pada tumbuhan kelapa akan muncul akar serabut.

Berdasarkan uraian di atas, menunjukkan bahwa kesalahan konsep pada materi tumbuhan sebagian besar terjadi pada konsep fotosintesis, respirasi dan akar tanaman serta keping 
biji. Konsep-konsep tentang tumbuhan ini menjadi materi yang diberikan dalam pembelajaran di tingkat Madrasah Ibtidaiyah, untuk itu diperlukan adanya penguasaan konsep yang lebih baik sehingga pemahaman siswa menjadi lebih baik juga.

b. Hewan

Hasil tes tulis dan wawancara terhadap respon tentang materi hewan tidak banyak konsep yang dapat di analisis. Hal ini dimungkinkan pengetahuan responden tentang materi hewan tidak terlalu banyak, sehingga peneliti kesulitan mendeteksi apakah guru memiliki pemahaman yang benar atau tidak.

Beberapa konsep yang berhasil digali dalam penelitian ini antara lain adalah pemahaman responden tentang hewan yang hidup di air selalu bernafas menggunakan insang, atau dengan kata lain hewan yang hidup di air akan menggunakan alat yang benama insang untuk bernafas. Bahkan ada sebagian responden yang menyatakan bahwa udang adalah salah jenis ikan. Pemahaman seperti ini jika disampaikan ke siswa akan menyebabkan pemahaman yang salah. Insang merupakan salah satu alat pernafasan yang memiliki fungsi untuk mengambil $\mathrm{O}_{2}$ yang berasal dari air, alat ini tentunya berbeda cara kerjanya dengan paru-paru atau trakea meskipun memiliki fungsi yang sama sebagai alat untuk mengambil $\mathrm{O}_{2}$.

Contoh hewan laut yang memiliki alat pernafasan berupa paruparu adalah ikan lumba-lumba. Hewan ini memiliki kelebihan mampu mengambil udara dari atas air dengan kapasitas cukup banyak untuk dimasukkan dalam kantung udara. Kantung udara pada ikan lumba-lumba akan bergetar dan mampu menimbukan bunyi dengan frekuensi yang sangat tinggi. Inilah salah satu faktor yang menyebabkan ikan lumba-lumba dapat mengeluarkan bunyi, atau bersuara.

c. Air

Pada materi tentang air, responden memberikan pernyataan bahwa "air laut berwarna biru karena adanya pembiasan dari langit". Konsep ini jika dibiarkan akan memberikan pemahaman kepada siswa bahwa langit memiliki warna, sedangkan kita sendiri tidak mengetahui batasan dari langit atau alam semesta ini. Hal ini terbukti dari tidak adanya responden yang benar- 
benar mengetahui adanya warna langit yang mempengaruhi warna air laut. Dari pernyataan ini menunjukkan bahwa responden sebenarnya tidak mengetahui tentang penyebab warna biru di angkasa maupun di air laut. Jika konsep yang salah ini disampaikan ke siswa tentu akan membuat siswa memiliki pemahan yang salah juga.

Warna biru dari air laut maupun angkasa, sebenarnya disebabkan karena pembiasan sinar matahari. Seperti diketahui bahwa sinar matahari memiliki rentang sinar dari biru sampai merah. Sinar biru, merupakan sinar matahari dengan panjang gelombang terpendek, sehingga saat mengenai atmosfer akan segera dipantulkan lagi oleh atmofer. Hal ini meyebabkan atmosfer akan tampak seperti berwarna biru. Warna ini akan memantul ke air laut, sehingga air laut seakan akan juga berwarna biru.

d. Panas dan Suhu

Salah satu pembahasan dalam pembelajaran sains di Madrasah Ibtidaiyah adalah tentang panas suatu benda dalam hal ini adalah energi panas dan suhu suatu benda. Dalam kehidupan seharihari kita sering merasakan panas dari suatu benda atau akibat dari tinggi atau rendahnya suhu suatu benda. Tetapi sering kali kita memahami antara suhu dan panas secara kurang tepat. Pemahaman tehadap konsep suhu atau panas, yang kurang tepat kemungkinan disebabkan karena kurang tepatnya pemahaman terhadap faktor yang mempengaruhi panas.

Panas merupakan salah satu bentuk energi atau sering disebut dengan kalor. Seperti sifat dari energi yang lain, kalor atau panas juga memiliki sifat tidak dapat dihilangkan atau dibentuk tetapi dapat berubah menjadi energi lain atau karena perubahan energi lain menjadi energi panas. Peristiwa ini disebut juga hukum kekekalan energi.

Suhu merupakan salah satu dari faktor yang mempengaruhi panas atau kalor. Faktor yang dapat mempengaruhi panas atau kalor suatu benda adalah suhu benda, volume benda dan massa jenis benda. Jika suatu benda yang sama dan memiliki suhu yang sama tetapi memiliki volume berbeda maka dapat memiliki panas atau kalor yang berbeda. 
Untuk membedakan suhu dan panas dalam pembelajaran sains dapat dilakukan dengan cara berikut:

1. Siapkan satu kotak tanah, keramik dan seng, Panaskan masing-masing benda tersebut dengan ukuran waktu yang sama (bisa dengan sinar matahari atau pemanas), kemudian ukur panas atau kalornya, atau jika tidak terlalu panas dapat dirasakan dengan indra.

2. Siapkan air dengan ukuran $250 \mathrm{~mL}$ liter dan $5000 \mathrm{~mL}$, panaskan air tersebut sampai keduanya mencapai suhu $90{ }^{\circ} \mathrm{C}$. kemudian ukur panasnya, atau mungkin kita dapat membayangkan panas air dengan volume $5000 \mathrm{~mL}$ jika terkena kulit.

Berdasarkan penjelasan tersebut di atas dapat diketahui bahwa panas dan suhu adalah berbeda, karena suhu adalah derajat panas dinginnya suhu benda yang menjadi salah satu faktor yang dapat mempengaruhi panas.

e. Cahaya

Cahaya memiliki sifat seperti gelombang, dimana gelombang cahaya merupakan materi yang mampu melaju dengan kecepatan sekitar $3.10^{9} \mathrm{~m} / \mathrm{s}$. Gelombang cahaya mampu mengahantar materi yang dibawanya dengan kecepatan yang sangat tinggi tanpa sedikitpun kehilangan materi yang dibawanya (tidak kurang maupun bertambah), dengan kata lain memiliki tingkat kejujuran $100 \%$.

Pembiasan merupakan salah satu sifat cahaya yang sering kita jumpai dalam kehidupan sehari-hari, misalnya adanya pelangi jika hujan atau setelah terjadi hujan. Sering kali kita mengatakan atau memiliki pemahaman bahwa pelangi dihasilkan karena adanya hujan atau pelangi hanya dapat terjadi jika ada hujan. Peristiwa adanya pelangi adalah karena pembiasan sinar matahari oleh titik embun atau uap air yang masih tersisa di udara. Pembiasan ini akan mengakibatkan warna dari sinar matahari akan terurai. Uraian warna dari sinar matahari akan membentuk pelangi dari sinar warna dengan panjang gelombang terendah sampai panjang gelombang tertinggi. 
Untuk menguraikan sinar matahari sebenarnya bukan hanya menunggu terjadinya hujan. Sinar matahari juga dapat diuraikan dengan menggunakan alat prisma. Sedangkan jika ingin menguraikan sinar matahari seperti halnya terjadinya pelangi, dapat dilakukan dengan melakukan percobaan pembiasan sinar melalui pembuatan embun atau uap air buatan.

Berdasarkan penjelasan di atas menunjukkan bahwa, pembiasan sinar matahari yang dapat menghasilkan pelangi tidak hanya dapat terjadi jika ada hujan. Pelangi merupakan proses pembiasan sehingga dapat dilakukan melalaui praktikum pembiasan cahaya. Pemahaman yang kurang tepat di atas dimungkinkan karena ketidaktepatan pemahaman konsep tentang sifat cahaya atau juga karena keterbatasan pemahaman tentang sifat cahaya.

f. Tata Surya

Matahari dalam tata surya kita dalam teori pada saat ini masih dianggap sebagai pusat sistem. Sistem tata surya merupakan sistem yang terdiri dari benda-benda langit dengan salah satu bintang sebagai pusat edar. Dalam tata surya kita matahari merupakan pusat edar, sehingga matahari dikelilingi oleh benda langit lainnya dengan garis edar tertentu.

Salah satu benda langit yang mengelilingi matahari adalah bumi. Bumi memiliki garis edar berbentuk eklip. Bumi mengelilingi matahari sekali dalam satu tahun dan berputar pada porosnya satu kali dalam satu hari atau sebanyak 365 kali dalam satu tahun. Seperti kita lihat dalam kehidupan kita sehari-hari, seakan-akan matahari akan muncul (terbit) pada pagi hari di sebelah timur dan menghilang (tenggelam) di sebelah barat. Bahkan dalam teks atau juga sering kita mengucapkan kata terbit atau tenggelam pada matahari.

Kenyataan yang kita lihat, dengan adanya matahari terbit di sebelah timur dan tenggelam di sebelah barat menujukkan bahwa matahari bukan sebagai pusat. Teori Geosentris mengatakan bahwa bumi adalah pusat tata surya. Jika mengacu pada teori ini, maka pernyataan matahari terbit dari sebelah timur dan tenggelam di sebelah barat dapat dibenarkan. Tetapi teori Geosentris sudah tidak lagi dianggap benar, teori yang sekarang dianggap benar adalah Heliosentris. 
Teori Heliosentris merupakan merupakan teori tentang adanya matahari sebagai pusat tata surya. Hal ini menunjukkan bahwa matahari tidak mungkin akan terbit atau tenggelam, karena sesungguhnya yang bergerak adalah bumi. Ukuran dan kecepatan bumi yang cukup besar akan menyebabkan kita sebagai makhluk bumi akan mengalami efek dari gerakan tersebut. Efek kecepatan gerak benda dapat juga kita rasakan jika kita naik kendaraan misalnya kereta api. Jika kita naik kereta api dengan kecepatan yang cukup tinggi dan kita melihat rel dari pintu sambungan antar gerbong kereta, maka seakan-akan rel tersebut akan bergerak, tetapi sesungguhnya rel tersebut diam dan kereta yang bergerak.

Berdasarkan penjelasan tersebut di atas menunjukkan bahwa sesungguhnya matahari tidak mungkin terbit atau tenggelam. Matahari merupakan pusat tata surya dan bumi bergerak mengelilinginya. Pemahaman ini penting untuk diberikan secara benar ke peserta didik sehingga mereka tidak mengalami kesalahan dalam memahami teori tentang tata surya yang lainnya.

Kesalahan pemahaman yang terjadi di atas dimungkinkan dan memberikan pengaruh terhadap penguasaan konsep siswa atau peserta didik. Hal ini terjadi jika interaksi maupun kepercayaan siswa terhadap guru sangat tinggi. Kesalahan yang terjadi dimungkinkan karena latar belakang pendidikan yang diperoleh oleh pendidik atau guru, meskipun mereka menjadi guru kelas dalam waktu yang cukup lama. Untuk itu perlu adanya bimbingan yang cukup intensif sehingga akan memberikan pemahaman yang benar, sehingga kesalahan pemahaman tidak terjadi atau dialami pendidik atau guru secara terus menerus. Pemahaman yang benar oleh guru sangat penting untuk menjadi modal pembelajaran sehingga siswa juga memiliki pemahaman yang benar.

\section{F. Kesimpulan}

Pemahaman guru kelas Madrasah Ibtidaiyah Non PGMI/PGSD terhadap materi sains di Madrasah Ibtidaiyah masih dianggap kurang atau perlu ada peningkatan. Kesalahan konsep yang terjadi pada guru Madrasah Ibtidaiyah Non PGMI/PGSD terhadap materi pembelajaran sains di Madrasah Ibtidaiyah hampir terjadi pada semua materi, antara lain terjadi pada materi tentang tumbuhan, hewan perubahan materi (air dan larutan) cahaya dan tata surya. 


\section{Daftar Pustaka}

Altun, E.H. \& Kaya, S. 1996. “Measurement of the Confidence, Attitude and Self-image of Turkish Student-Teachers in Relation to Chemistry Education. International Journal Science Education, 18(5): 569-576.

Arikunto, S. 2002. Prosedur Penelitian Suatu Pendekatan Praktek. Jakarta: Rineka Cipta.

Berg, V.D. 1991. Miskonsepsi Fisika dan Remidiasi. Sebuah Pengantar Berdasarkan Lokakarya di Universitas Kristen Satya Wacana Salatiga 7 - 10 Agustus 1990. Salatiga: Universitas Kristen Satya Wacana.

Dahar, R.W. 1988. Teori-Teori Belajar. Jakarta: P2LPTK.

Griffiths, A.K. \& Preston, K.R. 1992. “Grade-12 Student's Misconceptions Relating to Fundamental Characteristics of Atoms and Molecules". Journal of Research in Science Teaching, 29(6): 611-628.

Herron, D.J. 1996. The Chemistry Classroom Formulas for Successful Teaching. Washington, D.C: American Chemical Society.

Ibnu, S. 1989. Kesalahan Atas Konsep-Konsep IPA Karena Ketidaktepatan Pendekatan Yang Digunakan. Kumpulan Makalah. Malang.

Middlecamp, C. \& Kean, E. 1985. Panduan Belajar Kimia Dasar. Jakarta: Gramedia.

Nakhleh, M.B. 1992. “Why Some Student's Don't Learn Chemistry: Chemical Misconceptions". Journal of Chemical Education, 69 (3): 191-195.

Sastrawijaya, T. 1998. Proses Belajar Mengajar Kimia. Jakarta: Depdikbud.

Suparno, P.1997. Filsafat Konstruktivisme Dalam Pendidikan. Yogyakarta: Kanisius.

Taber, K.S. 1994. "Misunderstanding The Ionic Bonding". Journal of Chemical Education, 31(6): 100-103.

Wiseman, F.L. 1981. "The Teaching of College Chemistry: Role of Student Development Level". Journal of Chemical Education, $58(6)$ : 484-488. 
